\title{
ОСНОВНІ НАПРЯМКИ АНАЛІТИЧНОЇ ПОЛІТИЧНОї ФІЛОСОФІї
}

\author{
Я.В.Шрамко
}

\begin{abstract}
Анотація. Сучасна політична філософія аналітичного спрямування демонструє наявність великого спектру течій, концептуальних підходів та конкретних теорій, які розглядають найрізноманітніші проблеми політичного життя суспільства. Всі ці проблеми зрештою зводяться до проблеми суспільного блага - в чому воно полягає і як його можливо (якщо взагалі можливо) досягти. Суспільне благо слід розуміти тут гранично широко, не як набір якихось конкретних матеріальних або духовних благ, а як те, що Арістотель називав «благим життям», заради якого люди, власне, і об'єднуються в суспільство і яке передбачає вищу ступінь індивідуальної і суспільної досконалості (в першу чергу, моральної). 3 огляду на те, що досягнення суспільного блага можливе лише за умови, що суспільство грунтується на ідеї справедливості, одним з центральних завдань політичної філософії стає теоретична експлікація саме цієї ідеї - дати пояснення, в чому вона має полягати і яким чином суспільство і держава можуть і повинні їй відповідати. Ця ідея виступає засадничою для інших суспільних цінностей, найважливіші з яких знайшли своє вираження в знаменитому гаслі Великої французької революції: «Свобода, рівність, братерство!». Залежно від того, яка цінність приймається як визначальна для розв'язання проблеми справедливості, можна виділити чотири основні напрями сучасної аналітичної політичної філософії: утилітаризм (користь), лібералізм (свобода), егалітаризм (рівність), комунітаризм (спільність). Згідно з утилітаризмом, в основі справедливості, як і будь-яких інших понять моральної і політичної філософії, лежить принцип корисності. Соціально-політичні концепції ліберального типу визнають свободу за основну політичну цінність. Теорії егалітаризму розрізняються між собою залежно від концепції рівності, яку вони приймають. Відповідно до уявлень комунітаризму, в центрі політико-філософського розгляду взагалі і концепції соціальної справедливості зокрема повинні знаходитися не окремі індивіди, а спільноти людей і суспільство загалом.
\end{abstract}

Ключові слова: політична філософія, соціальна філософія, суспільне благо, соціальна справедливість.

\section{The MAIN DiRections of ANALYTICAL POLITICAL PHILOSOPHY}

Abstract. Modern political philosophy of analytical direction demonstrates the existence of a wide range of trends, conceptual approaches and specific 
theories that address a variety of issues in the political life of society. All these problems ultimately come down to the problem of the public good - what it is and how it is possible (if at all possible) to achieve. The public good should be understood here very broadly, not as a set of some specific material or spiritual goods, but as what Aristotle called the «good life», for which people, in fact, unite in society and which provides a higher degree of individual and social perfection (first of all, moral). Given that the achievement of the public good is possible only if society is based on the idea of justice, one of the central tasks of political philosophy is the theoretical explication of this idea - to explain what it should be and how society and the state can and must meet it. This idea is fundamental to other social values, the most important of which found expression in the famous slogan of the French Revolution: «Freedom, equality, brotherhood!». Depending on the value accepted as decisive for solving the problem of justice, we can distinguish four main directions of modern analytical political philosophy: utilitarianism (utility), liberalism (freedom), egalitarianism (equality), communitarianism (comunity). According to utilitarianism, the basis of justice, as well as any other concepts of moral and political philosophy, is the principle of usefulness. Socio-political conceptions of the liberal type accept freedom as the main political value. Theories of egalitarianism differ from each other depending on the concept of equality they adopt. According to the communitarian conception, the center of political and philosophical consideration in general and the concept of social justice in particular should deal not with particular individuals, but with communities and society in general.

Keywords: political philosophy, social philosophy, public good, social justice.

Сучасна політична філософія аналітичного спрямування демонструє наявність великого спектру течій, концептуальних підходів та конкретних теорій, які розглядають найрізноманітніші проблеми політичного життя суспільства. Всі ці проблеми зрештою зводяться до проблеми суспільного блага - в чому воно полягає і як його можливо (якщо взагалі можливо) досягти. Суспільне благо слід розуміти тут гранично широко, не як набір якихось конкретних матеріальних або духовних благ, а як те, що Арістотель називав «благим життям», заради якого люди, власне, і об'єднуються в суспільство і яке передбачає вищу ступінь індивідуальної і суспільної досконалості (в першу чергу, моральної). ${ }^{1} 3$ огляду на те, що досягнення суспільного блага можливе лише за умови, що суспільство грунтується на iдеї справедливості, одним з центральних завдань політичної філософії стає теоретична експлікація саме цієї ідеї - дати пояснення, в чому вона має полягати і яким чином суспільство і держава можуть і повинні їй відповідати. Ця ідея виступає засадничою для інших суспільних цінностей, найважливіші з яких знайшли своє вираження у знаменитому гаслі Великої французької революції: «Свобода, рівність, братерство!».

${ }^{1}$ Див.: Apicmomeлъ. Політика, III, 1280a, 32-33. 


\section{1. Утилітаризм}

Згідно з класичним утилітаризмом Єремії Бентама і Джона Стюарта Мілля, в основі справедливості, як і будь-яких інших понять моральної і політичної філософії, лежить принцип корисності, що виступає фундаментальним мірилом моралі, яким оцінюється поведінка людей в суспільстві і самий суспільний устрій, і за допомогою якого встановлюється, що в суспільній поведінці і суспільному устрої є правильним, а що - неправильним. Цей принцип стверджуе, що правильним слід вважати таку дію, або поведінку, або суспільний устрій, які є максимально «корисними». При цьому, під корисністю розуміється індивідуальне щастя, або благополуччя, або добробут окремих людей - членів суспільства. Інакше кажучи, правильними є такі дії і такий устрій суспільства, які ведуть до якомога більшого добробуту («щастя») якомого більшої кількості його членів. Цьому принципу підпорядковуються всі інші моральні та соціальні принципи, в тому числі, принцип справедливості. За висловом Мілля, справедливість $є$ не чим іншим, як «певним видом або відгалуженням корисності». ${ }^{2}$

Очевидно, класичне формулювання принципу корисності є занадто широким i, щоб бути застосовним, воно потребує конкретизації. Так, слід прояснити, що маємо розуміти під «корисністю» і яким чином ㄲï можна виміряти, якщо це взагалі можливо. Як визначається коло осіб, благополуччя яких береться до уваги? Чи повинен принцип корисності застосовуватися до окремих вчинків, або ж до загальних правил, які регулюють такі вчинки? Чи потрібно оцінювати актуальні (реальні) наслідки вчинків або ж їх потенційний (передбачуваний) ефект? Залежно від відповідей на ці та інші питання, формуються різні конкретні концепції утилітаристського типу, широко представлені в сучасній аналітичної філософії.

Уже Дж. Мур, який стояв біля витоків аналітичного руху, висунув важливе узагальнення принципу корисності у своїй теорії «ідеального утилітаризму». ${ }^{3}$ При інтерпретації того, що слід вважати «корисним», Мур відкидає моністичний гедонізм (що визначає благополуччя в простих термінах задоволення і невдоволення) і замість цього розглядає сукупність внутрішніх цінностей, до яких він відносить особливі якості свідомості, такі як переживання прекрасного, любов, дружбу тощо.

${ }^{2}$ Mill J.S. Utilitarianism // Collected works of John Stuart Mill. - Vol. X. - University of Toronto Press, 1969. - P. 241.

3 Див.: Moore G.E. Principia Ethica. - Amherst, New York: Prometheus Books, 1988. 
Різноманіття цих цінностей утворює певну «органічну цілісність», яка й повинна збільшуватися в результаті правильних дій.

Залежно від того, чи застосовується принцип корисності до дій безпосередньо або опосередковано, розрізняють «утилітаризм дій» $\mathrm{i}$ «утилітаризм правил». Перший піддає оцінці кожну окрему дію і комплекси дій. Ця версія утилітаризму є найбільш очевидною формою консеквенціалізму, - такого типу нормативної теорії, що ставить оцінку діяльності (індивідуальну і суспільну) в пряму залежність від наслідків цієї діяльності. Ці наслідки, в свою чергу, можуть бути актуальними або тільки очікуваними, що призводить до розрізнення між об'єктивно правильними діями (які дійсно призводять до зростання благополуччя) і суб'єктивно правильними діями (щодо яких можна очікувати, що вони призведуть до такого зростання). На відміну від такого дещо прямолінійного підходу, утилітаризм правил вважає дію правильною, якщо вона відповідає певним правилам, прийняття яких призводить до зростання загального блага.

Загалом, утилітаризм, у будь-якому його варіанті, належить до «телеологічної» парадигми моральної і політичної філософії, в якій людські вчинки та устрій суспільства обгрунтовуються, в кінцевому підсумку, інтересами досягнення певних цілей, що стоять перед людиною і суспільством. Для утилітаризму такою метою оголошується максимально більше щастя окремих людей і суспільства загалом.

\section{2. Лібералізм}

Соціально-політичні концепції ліберального типу визнають свобо$\partial y$ за основну політичну цінність. Поняття свободи $є$ доволі нечітким і потребує уточнення. Таке уточнення, однак, може бути здійснене в різних напрямках. Для аналітичної філософії важливим є розрізнення між негативною та позитивною свободою, ретельно проведене Ісайєю Берліном. ${ }^{4}$ Під негативною свободою розуміється відсутність обмежень з боку зовнішніх (суспільних) сил, а позитивна свобода означає можливість контролювати свої дії і життя загалом, можливість ставити перед собою цілі і досягати їх. Незважаючи на те, що ці види свободи взаємопов'язані і взаємозумовлені (відсутність обмежень відкриває можливість для дій i, навпаки, наявність такої можливості означає відсутність обмежень), розрізнення між ними має важливе значення,

${ }^{4}$ Berlin I. Two concepts of liberty // I. Berlin, Liberty. - London : Oxford University Press, 2002. - P. 166-217. 
оскільки виражає певну ієрархію ступенів свободи, в якій негативна свобода грає роль основи і необхідної умови.

Саме через негативну свободу формулюється те, що іноді називають «фундаментальним принципом лібералізму»: Нав'язування особистості будъ-чого (або примус особистості до будъ-чого) має бути належсим чином обгрунтоване; невиправданий примус (нав'язування) е несправедливим. ${ }^{5}$

Прийняття цього принципу має важливі наслідки для експлікації політичної структури суспільства, зокрема цей принцип вимагає обов'язкового обгрунтування будь-яких обмежень громадянських свобод з боку владних структур, і загалом, з боку держави. 3 огляду на те, що сутнісною ознакою держави є монополія на насильство, така постановка питання призводить до проблеми обгрунтування держави як такої.

Класичний інструмент такого обгрунтування був розроблений в теоріях суспільного договору, які історично є й першими концепціями лібералізму. Ці концепції висунули ідею природних прав людини, які не можуть бути відчужені або обмежені інакше як на законних підставах, при тому, що закон є результатом вільного і добровільного волевиявлення (суспільного договору). У сучасній політичній філософії оновлена версія цього методологічного інструменту була з успіхом застосована Джоном Ролзом в його ліберальній теорії справедливості як чесності. Проте існують і інші (недоговірні) стратегії виправдання держави, що використовують, наприклад, методологію «невидимої руки», пояснювальну силу якої продемонстрував Роберт Нозік у своїй лібертаріанській концепції мінімальної держави. ${ }^{6}$ Відповідно до такого пояснення, мінімальна держава $є$ необхідним (і ненавмисним) продуктом сукупних людських дій, у процесі яких кожен член суспільства переслідує власні цілі, але результат яких в точності не збігається ні 3 однією з них.

Загалом для лібералізму будь-якого напряму характерними є методологічний, нормативний і онтологічний індивідуалізм. Суспільство витлумачується як асоціація індивідів, кожен з яких є носієм прав і обов'язків. Кожен окремий індивід, його життя і благополуччя є найвищою цінністю самі по собі, а не з точки зору їх внеску в життя суспільства і суспільне благо. Легітимне використання примусу щодо вільних індивідів допустиме лише з метою запобігання або нейтралі-

${ }^{5}$ Див.: Gaus G. Justificatory Liberalism: An Essay on Epistemology and Political Theory. - New York: Oxford University Press, 1996. - P. 165.

${ }^{6}$ Nozik R. Anarchy, State, and Utopia. - New York: Basic Books, 1974. 
зації посягань з їх боку на законні права інших індивідів. Саме цим обмеженням визначається допустимий обсяг насильства до членів суспільства з боку політичних інститутів.

У сучасній аналітичної філософії представлений широкий спектр політичних теорій ліберального типу - від анархо-капіталізму до соціального лібералізму. Серед найбільш впливових мислителів другої половини XX - початку XXI ст., які розробляли різні концепції політичного та економічного устрою суспільства на ліберальних принципах, вирізняються Фрідріх фон Гайек, Мілтон Фрідман, Карл Поппер, Джон Ролз і Роберт Нозік.

\section{3. Егалітаризм}

Серед основних політичних цінностей ідеал рівності посідає особливе місце. Рональд Дворкін висловив ідею, що більшість сучасних політико-філософських теорій певною мірою втілюють цей ідеал як фундаментальну цінність, а значить, всі такі теорії можна вважати в певному сенсі «егалітаристськими». ${ }^{7}$ У цьому сенсі можна вести мову, наприклад, про «утилітарні концепції рівності» або «ліберальні концепції рівності». Проте, можна стверджувати, що в такого роду концепціях ідеал рівності все ж має підпорядковане (або інструментальне) значення для забезпечення деякої вищої цінності (корисності в утилітаризмі і свободи в лібералізмі). Це особливо наочно видно в теорії Ролза, де серед принципів справедливості принцип свободи має пріоритет над принципом рівності. Якщо ж ми говоримо про дійсний егалітаризм як самостійний політико-філософський напрямок, то тут саме рівність має виступати основною цінністю, першість якої над усіма іншими є вирішальною у справі організації справедливого суспільства.

Загалом можна стверджувати, що теорії егалітаризму розрізняються між собою залежно від концепції рівності, яку вони приймають. При цьому, може йтися про різні види рівності - політичну, правову, соціальну та економічну. Луїс Пожман проводить межу між формальними і змістовними концепціями рівності, в залежності від того, яким чином тлумачиться саме це поняття і здійснює детальний аналіз різновидів цих концепцій. ${ }^{8}$ До концепцій першого типу відносяться:

${ }^{7}$ Див.: Kymlicka W. Contemporary Political Philosophy: An Introduction. Oxford: Oxford University Press, 2002. - P. 3.

${ }^{8}$ Див.: Pojman L. Theories of equality: a critical analysis // Behavior and Philosophy. - 1995. - Vol. 23. - P. 1-27. 
1. Арістотелівське визначення рівності. Однакові випадки (предмети) завжди повинні трактуватися однаковим чином. «Якщо люди не рівні, вони не повинні отримувати однаково, саме тому спір і скарги виникають кожного разу, коли рівні мають і отримують не однаково, а нерівні, навпаки, отримують однаково». ${ }^{9}$

2. Рівність інтересів. Інтереси кожного члена суспільства повинні розглядатися як рівнозначні. ${ }^{10}$ Кожен член суспільства має право на однакове з іншими ставлення до себе і до своїх інтересів з боку суспільства і держави.

3. Презумпція рівності. До людей завжди слід підходити однаково, ставитися до них як до рівних, якщо тільки не існує вагомих підстав для нерівного ставлення. Тобто, має місце презумпція на користь рівного ставлення і проти нерівного.

4. Рівність перед законом. Всі повинні дотримуватися загального законодавства і нести однакову відповідальність за його порушення. Закон повинен застосовуватися неупереджено і одноманітно до всіх громадян, незалежно від їхнього матеріального та соціального стану.

5. Моральна рівність. Всі люди рівні в моральному відношенні, мають однакову моральну цінність і повинні підкорятися одним і тим самим нормам моралі.

Змістовні концепції рівності зазвичай будуються як розширення формальних концепцій. Вони не задовольняються чисто формальним визначенням рівності і намагаються встановити, завдяки чому саме до людей слід ставитися однаково, наслідком чого має бути й рівномірний розподіл тих чи тих благ. Змістовні концепції можуть перетинатися або доповнювати одна одну. Можна виділити два основні різновиди змістовних концепцій рівності, в залежності від того, чи розглядають вони вихідні умови людської діяльності або ж її наслідки: рівність можливостей і рівність результатів.

1. Рівність можливостей означає відсутність дискримінації членів різних соціальних груп (або суспільства загалом) при визначенні початкових умов і доступних для них варіантів у певних ситуаціях, які передбачають подальше отримання якихось благ (матеріальних або духовних).

2. Рівність результатів встановлюе вимогу, за яким суспільство повинно забезпечити рівний розподіл продукту, благ і соціального ста-

\footnotetext{
${ }^{9}$ Арістотелъ. Нікомахова етика, V, 1131a, 20-25.

${ }^{10}$ Mop.: Dworkin R. In defense of equality // Social Philosophy and Policy. - 1983. - Vol. 1/1. - P. 24.
} 
ну, які отримують його члени як винагороду за свою діяльність. Можливі декілька видів такого типу рівності:

2.1. Абсолютна рівність. Кожен повинен отримати однакову кількість всього. Така строга або «чиста» версія егалітаризму, незважаючи на всю свою спірність і нездійсненність, проте, має значення як граничний ідеал або ідеалізована модель, що лежить в основі егалітарного мислення як такого.

2.2. Рівність добробуту. Цей вид рівності відноситься до (матеріального) благополуччя членів суспільства, яке, при справедливому устрої, забезпечує рівний розподіл (матеріальних) благ і добробуту кожного індивіда.

2.3. Рівність ресурсів. Зрівнюванню підлягають не конкретні блага, а вся сукупність ресурсів, що використовуються людиною в процесі життєдіяльності, з урахуванням так званих «внутрішніх ресурсів» кожної людини, до яких відносяться її здібності, рівень обдарованості тощо. Можливі різні підходи до того, як забезпечити справедливий розподіл ресурсів:

2.3.1. Утилітарна рівність. Грунтується на знаменитому вислові Бентама: «Кожен рахується за одного і не більше, ніж за одного».

2.3.2. Економічна рівність. Багатство і доходи повинні перерозподілятися, з тим, щоб забезпечити для кожного рівний доступ до ресурсів і влади.

2.3.3. Політична рівністъ. Кожен член суспільства повинен володіти рівним набором політичних прав (таких як право обирати і бути обраним), що забезпечують його повноцінне політичне існування.

Як особливу змістовну концепцію рівності слід згадати і так звану «метафізичну рівність», яка стверджує рівність і однакову цінність усіх людей як таких, в силу однієї лише приналежності до людського роду, незалежно від їхніх природних здібностей, досягнень, особистих якостей і т. п. На такій ідеї вищої цінності особистості грунтується формулювання категоричного імперативу Канта, що вимагає завжди розглядати людину як мету, і ніколи - як засіб.

\section{4. Комунітаризм}

Наймолодшою серед течій сучасної політико-філософської думки аналітичного напряму є комунітаризм. Незважаючи на те, що ідеї комунітаризму беруть свій початок принаймні у «Політиці» Арістотеля, де підкреслюється суспільна природа людини і стверджується первин- 
ність соціальної спільності (поліса) над окремими людьми, ${ }^{11}$ сучасний аналітичний комунітаризм як самостійна концепція оформився в 8090-х роках XX ст. в результаті певної критики теорії справедливості Ролза (і ліберальної концепції справедливості загалом) з боку таких авторів як Аласдер Макінтайр, Майкл Сандел, Чарльз Тейлор і Майкл Волцер. ${ }^{12}$ Ця критика здійснювалася з позицій онтологічного і методологічного холізму, який стверджує, що суспільство не може бути зведеним просто до суми його членів і ніяке справжне пояснення суспільства на основі такого зведення неможливе.

Відповідно до уявлень комунітаризму, в центрі політико-філософського розгляду взагалі і концепції соціальної справедливості зокрема повинні знаходитися не окремі індивіди, а спільноти людей і суспільство загалом. Тільки будучи членами суспільства, долучаючись до цінностей спільності (однією з яких є солідарність), індивіди набувають моральну і соціальну значимість.

Центральним для комунітаристських концепцій є поняття загального блага. Комунітаристи відкидають ліберальні концепції справедливості саме через їхнюю недостатню увагу до цього поняття та надмірний наголос на особистій автономії і особистій свободі індивіда. Комунітарне розуміння справедливості обов'язково включає «культивування чесноти і роздуми про загальне благо». ${ }^{13}$ Необхідною умовою побудови справедливого суспільства є спільне вироблення поняття загального блага і колективні зусилля з облаштування суспільства відповідно до цих понятть. Громадяни справедливого суспільства повинні перейматися суспільними інтересами і тим самим піклуватися про загальне благо. «Комунітаристи стверджують, що основний інтерес індивіда полягає в тому, щоб його життя було морально добрим, а держава повинна допомогти індивідам жити таким життям, і вона повинна це робити шляхом сприяння загальному благу». ${ }^{14}$

Рассел Мюрхед зазначив цікаві паралелі в розвитку комунітаристських політико-філософських концепцій і певних процесів, які виявля-

${ }^{11}$ Аристотель, Политика, I, 1253a, 10-35.

12 Див.: Maclntyre A. After Virtue. - Notre Dame, Ind.: University of Notre DamePress, 1981; Sandel M. Liberalism and the Limits of Justice. - Cambridge: Cambridge University Press, 1982; Taylor C. Hegel and Modern Society. - Cambridge: Cambridge University Press, 1979; Walzer M. Spheres of Justice. - New York: BasicBooks, 1983.

${ }^{13}$ Sandel M. Justice. Justice. What's the Right Thing to Do? - New York: Farrar, Straus and Giroux, 2009. - P. 260.

${ }^{14}$ Campbell C. Persons, Identity, and Political Theory. A Defense of Rawlsian Political Identity. - Dordrecht, Heidelberg, London, New York: Springer, 2014. - P. 18. 
ються в політичному житті Великобританії і Сполучених Штатів. ${ }^{15} \mathrm{~A}$ саме, починаючи з 1980-х років, ідеологія соціальної держави (або держави загального добробуту) піддавалася в цих країнах серйозній критиці і партії, які відстоюють таку ідеологію, переживали глибоку кризу. Багато в чому реагуючи на таку критику, комунітаризм застерігає від небезпеки крайнього індивідуалізму, який повністю нехтує суспільними інтересами. Прихильники комунітаризму вважають, що лібералізм повинен звернути більшу увагу на роль громадянських обов'язків для успішного функціонування суспільства, а не обмежуватися традиційним підкресленням важливості прав людини. В цьому сенсі передбачається, що філософські концепції комунітаризму можуть сприяти виправленню недоліків ліберальної політики.

Загалом, слід ще раз підкреслити, що в аналітичній традиції доволі поширеним є підхід, згідно з яким політичну філософію слід розглядати під етичним кутом зору і сама політична філософія трактується як певна «частина етики». ${ }^{16}$ Етика має справу з категорією блага, потрактованого максимально широко, яке реалізується в загальних етичних цінностях, чеснотах, принципах і нормах. Політична філософія, витлумачена як свого роду «прикладна етика», виходить 3 поняття суспільного блага в найширшому сенсі, за допомогою якого обгрунтовуються інші соціально-політичні поняття: соціальної справедливості, рівності, свободи, прав людини та інші.

Моральна філософія утворює основу і встановлює межі для політичної філософії. Те, що люди можуть або не можуть робити по відношенню один до одного, обмежує те, що вони можуть робити за допомогою апарату держави або для створення такого апарату. Моральні заборони, які допустимо застосовувати, є джерелом будь-якої легітимності, яку має фундаментальна примушувальна влада держави. ${ }^{17}$

\section{5. Теорія справедливості Джона Ролза}

Як приклад, розглянемо одну з найвідоміших концепцій сучасної політичної філософії - теорію справедливості як чесності Джона

${ }^{15}$ Див.: Muirhead R. Communitarianism // The International Encyclopedia of Ethics. Edited by Hugh LaFollette, v. 2, Wiley-Blackwell, 2013. - P. 926-932.

${ }^{16}$ Див., напр.: Knowles D. Political Philosophy. - London : Routledge, 2001. - P. 3; Kymlicka $W$. Contemporary Political Philosophy: An Introduction. - Oxford University Press, 2002. - P. 5; Larmore C. What is political philosophy? // Journal of Moral Philosophy. - 2013. - Vol. 10. - P. 276-306.

${ }^{17}$ Див.: Nozik R. Anarchy, State, and Utopia. - New York: Basic Books, 1974. P. 6. 
Ролза. Ця теорія, розроблена і детально обгрунтована Джоном Ролзом в однойменній книзі 1971 року, є багато в чому парадигмальною для широкого спектра концепцій політичної філософії аналітичного напряму, перш за все, з точки зору методології постановки соціально-філософських проблем і їх подальшого аналізу і рішення. Ця методологія полягає в тому, що в центр розгляду поміщається категорія, яка має явно виражену етичну природу і яка наділяється статусом соціально-політичної цінності, після чого здійснюється теоретико-філософський аналіз умов можливості втілення даної цінності в суспільному устрої. При цьому, незважаючи на те, що теоретична експлікація обраної категорії обмежується соціальними процесами і феноменами, її загальноетичний характер повністю зберігається, що дозволяе потім поширити результати соціально-філософського аналізу на рішення загальних проблем моральної філософії.

У повній відповідності з класичною традицією, що бере початок від платонівської «Держави», Ролз приймає за таку центральну категорію політичної філософії категорію справедливості, яка в його теорії суспільства природним чином набуває характеру соціальної справедливості:

Справедливість є першою чеснотою соціальних інститутів, як істина є першою чеснотою систем думки. Якоб б елегантною і економною не була теорія, вона повинна бути відкинута або переглянута, якщо вона неістинна; точно так само й інститути, неважливо наскільки вони ефективні і добре організовані, мають бути реформовані або скасовані, якщо вони є несправедливими. ${ }^{18}$

Теорія Ролза спирається на два важливих положення. Перше - це тлумачення суспільства як особливої «системи кооперації, тобто, як «більш-менш самодостатньої асоціації людей, які в своїх відносинах визнають певні обов'язкові правила поведінки і які здебільшого діють відповідно до них». ${ }^{19}$ Будучи такою асоціацією індивідів, суспільство одночасно характеризується як збігом інтересів його членів, так i ïх конфліктом: з одного боку, всі члени суспільства зацікавлені в його існуванні, оскільки суспільство надає можливість кращого життя для кожного, в порівнянні з тим, що вони мали б поза ним; з іншого ж боку, має місце (принаймні, потенційний) конфлікт інтересів щодо можливого розподілу суспільних благ, що виникають в результаті функціонування суспільства. Таким чином, суспільство потребує основоположних

${ }^{18}$ Rawls J. A Theory of Justice. - Cambridge, MA : Harvard University Press, 1971. - P. 3.

${ }^{19}$ Ibid. - C. 4. 
принципів, які визначали б його устрій в умовах зазначеного конфлікту. Ці принципи і суть принципи справедливості: «вони визначають розподіл прав і обов'язків в основних громадських інститутах, а також переваги і тяготи соціальної кооперації». ${ }^{20}$ Суспільство може вважатися добре влаштованим, якщо воно організоване відповідно до деякої загальновизнаної концепції справедливості. Справа, таким чином, полягає у тому, щоб виробити таку концепцію.

Друге положення полягає у тому, що основним носієм соціальної справедливості, її суб'єктом, виступає не людина і навіть не окремі соціальні інститути, а «базова структура суспільства або, точніше, той спосіб, яким основні соціальні інститути розподіляють фундаментальні права і обов'язки і регулюють отримання вигод від соціальної взаємодії. ${ }^{21}$ Під основними соціальними інститутами Ролз має на увазі загальний політичний устрій і найважливіші економічні і соціальні порядки та умови існування суспільства. Такі інститути істотно визначають сукупність прав і свобод, якими можуть володіти члени суспільства, а також життєві перспективи останніх. У свою чергу, справедливий устрій соціальних інститутів безпосередньо залежить від справедливого устрою базової структури суспільства загалом.

Основна ідея Ролзівськой теорії справедливості полягає у тому, що принципи справедливості, яким повинна підпорядковуватись базова структура суспільства, є предметом суспільного договору і вони можуть бути обгрунтовані як такі принципи, що їх «вільні і раціональні особистості, які прагнуть просувати власні інтереси і перебуваючи в деякому початковому стані рівності, взяли б за принципи, що визначають основні умови їхньої асоціації». ${ }^{22}$ Таким чином, у Ролза ідея суспільного договору покликана грати набагато ширшу роль, у порівнянні з класичними теоріями Гоббса і Локка, в яких суспільний договір був безпосереднім способом легітимації державної влади. Ролз же використовує суспільний договір як певний методологічний інструмент, за допомогою якого досягається обгрунтування основних положень розвинутої ним концепції справедливості.

Для цього Ролз моделює деяку гіпотетичну «вихідну позицію», перебуваючи в якій вільні раціональні індивіди повинні виробити основні принципи справедливості для свого суспільства. Ця позиція аналогічна позадержавному «природному стану», як він розглядався в традиційних теоріях суспільного договору, хоча й істотно відрізняється від

\footnotetext{
${ }^{20}$ Ibid.

${ }^{21}$ Ibid. - P. 7.

${ }^{22}$ Ibid. - P. 11.
} 
нього, перш за все рівнем абстракції, а також конкретними умовами, яким ця ситуація повинна відповідати, щоб забезпечити максимальну чесність здійснюваного вибору. Йдеться про своєрідний уявний експеримент, для чого пропонується уявити деякі збори людей, мета яких полягає у спільному виробленні основних принципів справедливості, які мають бути прийняті в ході переговорів в результаті укладеної угоди і виходячи з яких буде надалі розроблятися весь суспільний устрій. Найважливіша попередня умова цих переговорів, яка є характеристичною для даної вихідної позиції, полягає в тому, що всі учасники переговорів перебувають за свого роду «завісою невідання», в тому сенсі, що ніхто з них не знає свого соціального статусу, класового і професійного стану, частки в суспільному продукті, своїх інтелектуальних і фізичних здібностей, рівня освіти, релігійної приналежності, ідеологічних переконань, моральних принципів тощо. Методологічне завдання змодельованої таким чином вихідної позиції для переговорів полягає в тому, щоб з'ясувати, якої концепцї справедливості дійдуть за таких умов їх учасники. На думку Ролза, оскільки всі учасники «знаходяться в однаковому становищі і ніхто не може підігнати шукані принципи під власні умови, принципи справедливості будуть результатом чесної угоди або домовленості». ${ }^{23}$ Іншими словами, найбільш справедливою базовою структурою суспільства буде та, яку раціональні особистості вільно оберуть, не маючи уявлення про власний (потенційний) стан у цьому суспільстві. ${ }^{24}$ у цьому сенсі, Ролз вважає свою теорію справедливості частиною теорії раціонального вибору. Обгрунтована у такий спосіб концепція отримала назву «справедливість як чесність».

У своїй основі, ця концепція є глибоко егалітарною, оскільки вона істотно орієнтується на ідеал рівності. Цей ідеал формулюється Ролзом у загальному вигляді таким чином:

Всі соціальні цінності - свобода і можливості, дохід, багатство і соціальні основи самоповаги - повинні розподілятися порівну, якщо тільки нерівний розподіл будь-яких або всіх з цих цінностей не приносить користь кожному. ${ }^{25}$

Така егалітарна установка не є, проте, зрівняльною, оскільки вона допускає нерівність, наприклад, при розподілі суспільних благ, як інструмент покращення життя всіх членів суспільства. Таким чином, будьякий прояв нерівності, який погіршує становище хоч якогось члена

\footnotetext{
${ }^{23}$ Ibid. - P. 12.

${ }^{24}$ Див.: Lovett F. Rawls's A Theory of Justice: a Reader's Guide. - London, New York: Continuum International Publishing Group, 2011. - P. 19.

${ }^{25}$ Ibid. - C. 62.
} 
суспільства, в порівнянні з тим, яким воно було б в умовах рівності, $є$ несправедливим. Виходячи з цього загального розуміння, Ролз приходить до двох основних принципів, яким повинна підпорядковуватись базова структура суспільства і всі соціальні інститути, щоб мати право вважатися справедливими. При цьому передбачається, що гіпотетичні учасники переговорів по виробленню цих принципів, які знаходяться у вихідній позиції, яка по суті є ситуацією невизначеності, можуть використовувати як корисний евристичний інструмент прийняття рішення, так зване «правило максиміну». Згідно з цим правилом, добре відомим у теорії ігор і теорії прийняття рішень, при виборі з декількох варіантів необхідно ретельно зважити наслідки всіх варіантів, виявити найгірший наслідок кожного з них і прийняти рішення на користь того варіанту, найгірший наслідок якого принесе найменшу шкоду. Такий спосіб дій характерний для так званого обережного або песимістичного вибору з боку раціонального суб'єкта. Справді, з огляду на те, що учасники переговорів перебувають у вихідній позиції за «завісою невідання» і їм невідомо, в якому суспільному становищі вони опиняться після того, як завіса буде прибрана, можна очікувати, що, визначаючи основні принципи устрою суспільного буття, вони не будуть занадто ризикувати і віддадуть перевагу таким принципам, які в достатній мірі захистять їх, навіть якщо їх положення в суспільстві виявиться найменш сприятливим.

В результаті, принципи справедливості як чесності виявляються такими:

1. Кожен має рівне право на найбільш широку систему основних свобод, сумісну з такою ж системою свобод для всіх інших (принцип рівного права на основні свободи).

2. Соціальна й економічна нерівність допускається тільки за умови іiї відповідності таким двом вимогам: (а) державні посади і суспільне становище, пов'язані з цією нерівністю, доступні для всіх членів суспільства за умови чесної рівності можливостей (принцип чесної рівності можливостей); (b) ця нерівність приносить максимальну вигоду для найменш забезпечених членів суспільства (принцип відмінності).

Ці принципи є ієрархічно впорядкованими, в тому сенсі, що виконання першого принципу має пріоритет перед виконанням другого, а в другому принципі перша його частина (а) має пріоритет перед другою частиною (b). Іншими словами, свобода може бути обмежена тільки заради неї самої (наприклад, свобода однієї людини обмежується правом на таку ж свободу іншої людини), але ніколи - для забезпечення доступу до якихось посад, а рівність можливостей ні за яких обставин 
не може бути обмежена міркуваннями матеріальної вигоди.

Такі основні риси теорії Джона Ролза, яка являє гарний приклад ліберальної концепції справедливості. Для цієї концепції, яка бере свій початок у моральній філософії Канта, характерна загалом яскраво виражена деонтологічна спрямованість, тобто, обгрунтування моралі через категорію обов'язку та утвердження пріоритету того, що є правильним, над добром.

«Деонтологічний лібералізм» перш за все є теорією справедливості, а саме, про першість справедливості серед моральних і політичних ідеалів. Його центральна теза може бути сформульована так: суспільство, що складається з безлічі індивідів, кожен з яких має свої цілі, інтереси і уявлення про благополуччя, побудовано найкращим чином, якщо воно регулюється принципами, які самі не передбачають ніякого конкретного поняття благополуччя; ці регулятивні принципи виправдовуються, в першу чергу, не тим, що вони максимізують суспільний добробут або якось ще сприяють благополуччю, але швидше тим, що вони підпорядковані поняттю правильності, моральної категорії, даної перед категорією благополуччя і незалежно від неї. ${ }^{26}$

\section{References}

[1] Aristotle. Nicomachean Ethics / R. Crisp (ed./trans.). - Cambridge : Cambridge University Press, 2000.

[2] Aristotle. Politics / E. Barker, R. Stalley (trans./rev.). - Oxford: Oxford University Press, 1995.

[3] Berlin I. Two concepts of liberty / I. Berlin Liberty. - London : Oxford University Press, 2002. - P. 166-217.

[4] Campbell C. Persons, Identity, and Political Theory. A Defense of Rawlsian Political Identity. - Dordrecht, Heidelberg, London, New York : Springer, 2014.

[5] Dworkin R. In defense of equality // Social Philosophy and Policy. 1983. - Vol. $1 / 1$.

[6] Gaus G. Justificatory Liberalism: An Essay on Epistemology and Political Theory. - New York: Oxford University Press, 1996.

[7] Knowles D. Political Philosophy. - London: Routledge, 2001.

${ }^{26}$ Sandel M. Liberalism and the Limits of Justice. - Cambridge : Cambridge Univ. Press, 1998. - P. 1. 
[8] Kymlicka W. Contemporary Political Philosophy: An Introduction. Oxford: Oxford University Press, 2002.

[9] Larmore C. What is political philosophy? // Journal of Moral Philosophy. - 2013. - Vol. 10.

[10] Lovett F. Rawls's A Theory of Justice: a Reader's Guide. - London, New York: Continuum International Publishing Group, 2011.

[11] Muirhead R. Communitarianism // The International Encyclopedia of Ethics. Edited by Hugh LaFollette. - Vol. 2. - Wiley-Blackwell, 2013.

[12] Maclntyre A. After Virtue. - Notre Dame, Indiana: University of Notre Dame Press, 1981.

[13] Mill J.S. Utilitarianism // Collected works of John Stuart Mill. Vol. X. - University of Toronto Press, 1969.

[14] Moore G.E. Principia Ethica. - New York: Prometheus Books, 1988.

[15] Nozik R. Anarchy, State, and Utopia. - New York : Basic Books, 1974.

[16] Pojman L. Theories of equality: a critical analysis // Behavior and Philosophy. - 1995. - Vol. 23.

[17] Rawls J. A Theory of Justice. - Cambridge, MA : Harvard University Press, 1971.

[18] Sandel M. Justice. What's the Right Thing to Do? - New York: Farrar, Straus and Giroux, 2009.

[19] Sandel M. Liberalism and the Limits of Justice. - Cambridge: Cambridge University Press, 1982.

[20] Taylor C. Hegel and Modern Society. - Cambridge : Cambridge University Press, 1979.

[21] Walzer M. Spheres of Justice. - New York: BasicBooks, 1983.

Надійшла до редакиї̈ 09 серпня 2020 р. 


\section{Шрамко Ярослав Владиславович}

Кафедра філософії

Криворізький державний педагогічний університет просп. Гагаріна, 54

м. Кривий Ріг

50086

Shramko Yaroslav

Department of Philosophy

Kryvyi Rih State Pedagogical University

Gagarina ave., 54

Kryvyi Rih

50086

(iD https://orcid.org/0000-0003-4843-0328

@shramko@rocketmail.com

doi $10.31812 /$ apd.v0i21.4370 